\title{
Biodegradation of Melamine and Cyanuric Acid by a Newly-Isolated Microbacterium Strain
}

\author{
Naofumi Shiomi", Maiko Ako \\ School of Human Sciences, Kobe College, Nishinomiya, Japan \\ Email: ${ }^{*}$ n-shiomi@mail.kobe-c.ac.jp
}

Received April 25, 2012; revised May 28, 2012; accepted June 11, 2012

\begin{abstract}
We searched for a superior melamine-degrading bacterium for the bioremediation of melamine. Cyanuric acid, which is a by-product produced during the biodegradation of melamine, shows strong nephrotoxicity. Therefore, the melamine-degrading bacterium is also required to show a high ability to degrade cyanuric acid. We selected a melamine-degrading strain (MEL1) among ten cyanuric acid-degrading bacteria isolated from the soil. The species of MEL1 strain was Microbacterium esteramaticum or was extremely similar to that species, and the enzymatic activity of the melamine deaminase in the MEL1 strain was similar to that in the NRRLB-12227 strain. The ability of the MEL1 strain to degrade cyanuric acid was higher than its ability to degrade melamine, and therefore, the accumulation of by-products (ammeline, ammelide and cyanuric acid) during the degradation of melamine was minimal. These results suggest that the MEL1 strain is useful for the bioremediation of melamine.
\end{abstract}

Keywords: Melamine; Cyanuric Acid; Melamine Deaminase; Microbacterium

\section{Introduction}

Melamine is used for the production of melamine resin and other products, and the current output of melamine resin in Japan is 140,000 ton/year. As a melamine molecule contains a very high level of nitrogen, the apparent content of protein can be increased by the intentional addition of the compound. In China, melamine was intentionally added to dairy products by some food industries in 2004-2007 [1]. Consequently, serious food-related toxicity occurred in subjects who consumed the dairy products. For example, numerous dogs and cats were poisoned (or died) after they ate pet food containing the adulterated dairy products in Korea and the USA [2-4]. In 2008, around 50,000 children suffered from renal failure and 6 children died because they were fed powdered milk contaminated with melamine. A later investigation uncovered that the products adulterated with melamine was not only limited to dairy products, but also included cakes and animal feed in China.

Melamine had been considered to be harmless, because the $\mathrm{LD}_{50}$ value is very high $(1-3 \mathrm{~g} / \mathrm{kg})$. However, recent studies suggest that its degradation product, cyanuric acid, causes the severe renal failure [5]. Cyanuric acid is a by-product that forms during the process of melamine production and the biodegradation of melamine. It combines with melamine in the kidney, and kidney stones

${ }^{*}$ Corresponding author. made of these compounds induce renal failure. The nephrotoxicity caused by the two compounds was much stronger than that in case of treatment with just melamine [6].

Melamine-containing waste water had been freely dumped into the environment without any treatment for many years until the above described food-related incidents occurred. Qin et al. [7] assessed the soil and waste water near melamine-manufacturing factories in China. The maximum concentrations in waste water and soil samples were 226.766 and $41.136 \mathrm{mg} / \mathrm{kg}$, respectively. Such contamination also caused the contamination of crops, and the maximum value of melamine contained in a wheat sample was $2.05 \mathrm{mg} / \mathrm{kg}$. Therefore, unexpected food accidents caused by the consumption of these crops may occur in the future. For these reasons, increasing attention has been paid to the bioremediation of soil and waste water contaminated by melamine.

Some melamine-degrading bacterial strains, such as Klebsiella terragena DRS-1 [8], Norcadioides sp. ATD6 [9], Pseudomonas sp. NRRL B-12227 [10] and Rhodococcus corallines NRRLB-15444R [11], have reportedly been used for bioremediation in previous research. Cyanuric acid is a key intermediate in the metabolic pathway of melamine. Rapid biodegradation of cyanuric acid is important for the bioremediation of melamine, because it is a nephrotoxic compound. However, the cleavage of cyanuric acid is a rate-limiting step in the above melamine-degrading strains. For example, the $K$. 
terragena DRS-1 and Norcadioides sp. ATD6 strains showed a high ability to degrade melamine, but a low ability to degrade cyanuric acid. Therefore, the utilization of a mixture of melamine and cyanuric acid-degrading strains is required to fully degrade melamine. On the contrary, the Pseudomonas sp. NRRL B-12227 showed the ability to degrade both cyanuric acid and melamine [12], and thus, this strain was considered to be profitable for the bioremediation of melamine. However, the strain was reclassified as Acidovorax citrulli [13]. A. citrulli is not a good species for bioremediation, because it is a serious plant pathogen for watermelon, therefore the isolation of a new strain is considered to be necessary.

In this study, we searched for a superior strain for the bioremediation of melamine. The newly-isolated Microbacterium strain showed a high ability to degrade cyanuric acid as well as melamine. Therefore, this strain may be useful for the bioremediation of melamine.

\section{Materials and Methods}

\subsection{Bacteria and Media}

The A. citrulli NRRL B-12227 strain was obtained from Agricultural Research Service. Modified Luria Bertani medium (LB medium; $10 \mathrm{~g} / \mathrm{L}$ bactopeptone, $10 \mathrm{~g} / \mathrm{L}$ yeast extract, $5 \mathrm{~g} / \mathrm{L} \mathrm{NaCl}, 1 \mathrm{~g} / \mathrm{L}$ glucose, $\mathrm{pH}$ 7.2) and DavisMiligano medium without ammonium sulfate (DM medium; $2 \mathrm{~g} / \mathrm{L}$ glucose, $7 \mathrm{~g} / \mathrm{L} \mathrm{K}_{2} \mathrm{HPO}_{4}, 3 \mathrm{~g} / \mathrm{L} \mathrm{KH}_{2} \mathrm{PO}_{4}, 0.1$ $\mathrm{g} / \mathrm{L} \mathrm{MgSO}_{4}, 0.1 \mathrm{~g} / \mathrm{L}$ yeast extract) were used for the culture of bacteria.

\subsection{Assays}

Cell growth was measured by the optical density (OD) of light passing through a $1 \mathrm{~cm}$ cuvette at $610 \mathrm{~nm}$. The concentration of protein was determined by a protein assay kit (Bio-Rad Laboratories, Inc., Tokyo, Japan). The concentrations of melamine, cyanuric acid, ammeline and ammelide in the culture broth (without cells) were determined by HPLC using an Asahipac GS-320 column (Shimazu Good Laboratory Component Ltd., Osaka, Japan). The mobile phase and the flow rate were $100 \mathrm{mM}$ $\mathrm{Na}_{2} \mathrm{HPO}_{4}(\mathrm{pH} 10.0)$ and $1.0 \mathrm{~mL} / \mathrm{min}$. The concentrations were determined by measuring the absorbance at $230 \mathrm{~nm}$. The concentration of simetryn and atrazine were determined by capillary gas chromatography using a DB-5 column $(0.25 \mathrm{~mm} \times 30 \mathrm{~m})$ equipped with a FID detector. The evaporation and detection temperatures were $300^{\circ} \mathrm{C}$, and the column temperature was gradually increased from $80^{\circ} \mathrm{C}$ to $300^{\circ} \mathrm{C}$ at a rate of $10^{\circ} \mathrm{C} / \mathrm{min}$.

\subsection{Isolation of Cyanuric Acid-Degrading Strains}

One gram of each soil sample collected from 100 dif- ferent places in Kyoto, Osaka and Hyogo prefectures in Japan was suspended in $10 \mathrm{~mL}$ of $0.85 \% \mathrm{NaCl}$ solution, and $0.1 \mathrm{~mL}$ of the suspension was spread on an agar plate of LB medium. The cells grown on the plates were collected and used for the screening. Around 1000 cells were spread on each agar plate with the DM medium containing $1.0 \mathrm{mM}$ cyanuric acid, and were cultured for 3 days at $37^{\circ} \mathrm{C}$. Ten strains from 20 plates showing large colonies were isolated as cyanuric acid-degrading strains, and then were used for the further analyses.

\subsection{Identification}

The identification of the isolated strain (MEL1) was performed using the following procedure by the NCIMB JAPAN Corporation: The nucleotide sequences of the 16S ribosomal DNA was determined with ABI PRISM 3100 DNA Sequencer (Applied Biosystems, CA, USA). A homology search of the sequence was performed with the database (Apollon DB-BA Ver. 7.0) from TechnoSulruga Laboratory Co. Ltd. (Sizuoka, Japan) and the phylogenic tree was constructed with the most closely related 10 species according to the neighbor-joining method [14]. A homology search was also performed using BLAST [15] with the DNA sequence database (GenBank/DDB/EMBL).

\subsection{Enzymatic Activity and Purification of Melamine Deaminase}

The A. citrulli NRRL B-12227 and the melamine-degrading (MEL1) strains were cultured in $200 \mathrm{~mL}$ DM media containing $1.0 \mathrm{~g} / \mathrm{L}$ of ammonium sulfate for 3 days. The cells in each culture were harvested and suspended in $3 \mathrm{~mL}$ of $10 \mathrm{mM}$ Tris- $\mathrm{HCl}$ buffer $(10 \mathrm{mM}$ Tris (hydroxymethyl)aminomethane (pH 7.5)). The cell suspension was disrupted with a cell disrupter (MINIBEADEATER, WAKENYAKU, Co. Ltd., Kyoto, Japan) by shaking with $1 \mathrm{~mL}$ of glass beads $(0.17-0.18 \mathrm{~mm} \phi)$ for $9 \mathrm{~min}$. The whole solution was centrifuged at 12,000 $\times \mathrm{g}$ for $15 \mathrm{~min}$. The supernatant was then put in a seamless cellulose tube (Wako Chem. Ind., Osaka, Japan) and dialyzed with $3 \mathrm{~L}$ of $10 \mathrm{mM}$ Tris- $\mathrm{HCl}$ buffer $(\mathrm{pH}$ 7.5) for 1 day. The resulting enzyme solution was used for the subsequent assays.

The melamine deaminase activity was measured according to the method described by Karns [10] with slight modification. A total of $900 \mu \mathrm{L}$ of $25 \mathrm{mM} \mathrm{TE}$ buffer ( $\mathrm{pH}$ 8.0) containing $3 \mathrm{mM}$ melamine and $100 \mu \mathrm{L}$ of the enzyme solution were incubated at $37^{\circ} \mathrm{C}$ for 1 day, and the decrease in melamine was measured using HPLC by sampling the solution every 3 hours.

The purification of melamine deaminase was performed in three steps. First, solid ammonium sulfate (final concentration: $20 \%$ ) was added to the rest of the en- 
zyme solution $(2.7 \mathrm{~mL})$ and incubated for $2 \mathrm{~h}$ at room temperature. After sedimentation and centrifugation at $12,000 \times \mathrm{g}$, the entire solution was put in a new tube. Solid ammonium sulfate (final concentration: 40\%) was added to the tube, and then a similar procedure was performed. The sediment from both steps was then dissolved in $3 \mathrm{~mL}$ of Tris- $\mathrm{HCl}$ buffer ( $\mathrm{pH} 7.5)$, put in seamless cellulose tubing (Wako Chem. Ind.) and dialyzed with $3 \mathrm{~L}$ of $10 \mathrm{mM}$ Tris- $\mathrm{HCl}$ buffer $(\mathrm{pH} \mathrm{7.5)}$ for 1 day. As the solution containing the sediment obtained following the addition of $20 \%$ ammonium sulfate showed the highest enzymatic activity, it was then used for further purification. Figures 1(a) and (b) show the elution profiles of the protein and the activities in each fraction in the DEAEcellulose and Sephadex G-100 columns. The solutions were applied onto a DEAE-cellulose column $(1 \mathrm{~cm} \times 24$ $\mathrm{cm})$ equilibrated with Tris- $\mathrm{HCl}$ buffer $(\mathrm{pH} 7.5)$. The adsorbed proteins were eluted by an increasing gradient of $\mathrm{KCl}$ in the same buffer $(0-1.0 \mathrm{M}, 500 \mathrm{ml})$ at a flow rate of $2.0 \mathrm{~mL}$ per fraction. The active fraction (fraction number 11) was pooled, and put onto a Sephadex G-100 column $(1.0 \times 96 \mathrm{~cm})$ equilibrated with Tris-HCl buffer ( $\mathrm{pH} 7.5$ ), and the protein was eluted with Tris- $\mathrm{HCl}$ buffer $(\mathrm{pH} 7.5)$ at a flow rate of $2.0 \mathrm{~mL}$ per fraction.

Water present in the active fraction (fraction number 3 ) was evaporated using a freeze drying method, and it was then dissolved in $20 \mu \mathrm{L}$ of Tris- $\mathrm{HCl}$ buffer ( $\mathrm{pH} 7.5$ ). Sodium dodecyl sulfate-polyacrylamido gelelectrophoresis
(SDS-PAGE; $10 \%$ acrylamide gel) of $5 \mu \mathrm{L}$ of purified protein solution was performed by the method described by Laemmli [16]. The molecular size of the proteins was determined with the Precision Plus Protein Standard (Bio-Rad Laboratories).

\subsection{Biodegradation of Melamine by the MEL1 Strain}

The MEL1 strain pre-cultured in $20 \mathrm{~mL}$ LB medium was inoculated at an optical density (OD) of 0.01 at $610 \mathrm{~nm}$ into $50 \mathrm{~mL}$ of four different kinds of media (DM media containing either $0.2 \mathrm{~g} / \mathrm{L}$ of melamine, $0.2 \mathrm{~g} / \mathrm{L}$ of cyanuric acid, $0.02 \mathrm{~g} / \mathrm{L}$ of ammeline or $0.02 \mathrm{~g} / \mathrm{L}$ of ammelide). The cells were cultured for 5 days at $37^{\circ} \mathrm{C}$ with shaking at $120 \mathrm{rpm}$. The $2 \mathrm{~mL}$ of culture broth was sampled every day, and the supernatant was separated from the cells by centrifugation at $12,000 \times \mathrm{g}$. The triazine compounds in the supernatant were measured by HPLC. Three independent experiments were performed.

\section{Results and Discussion}

\subsection{Isolation of a Strain Showing a High Ability to Degrade Cyanuric Acid and Melamine}

To search for a novel bacterium showing a superior ability to degrade melamine compared to the previously identified bacterial strains, we first performed a screen-
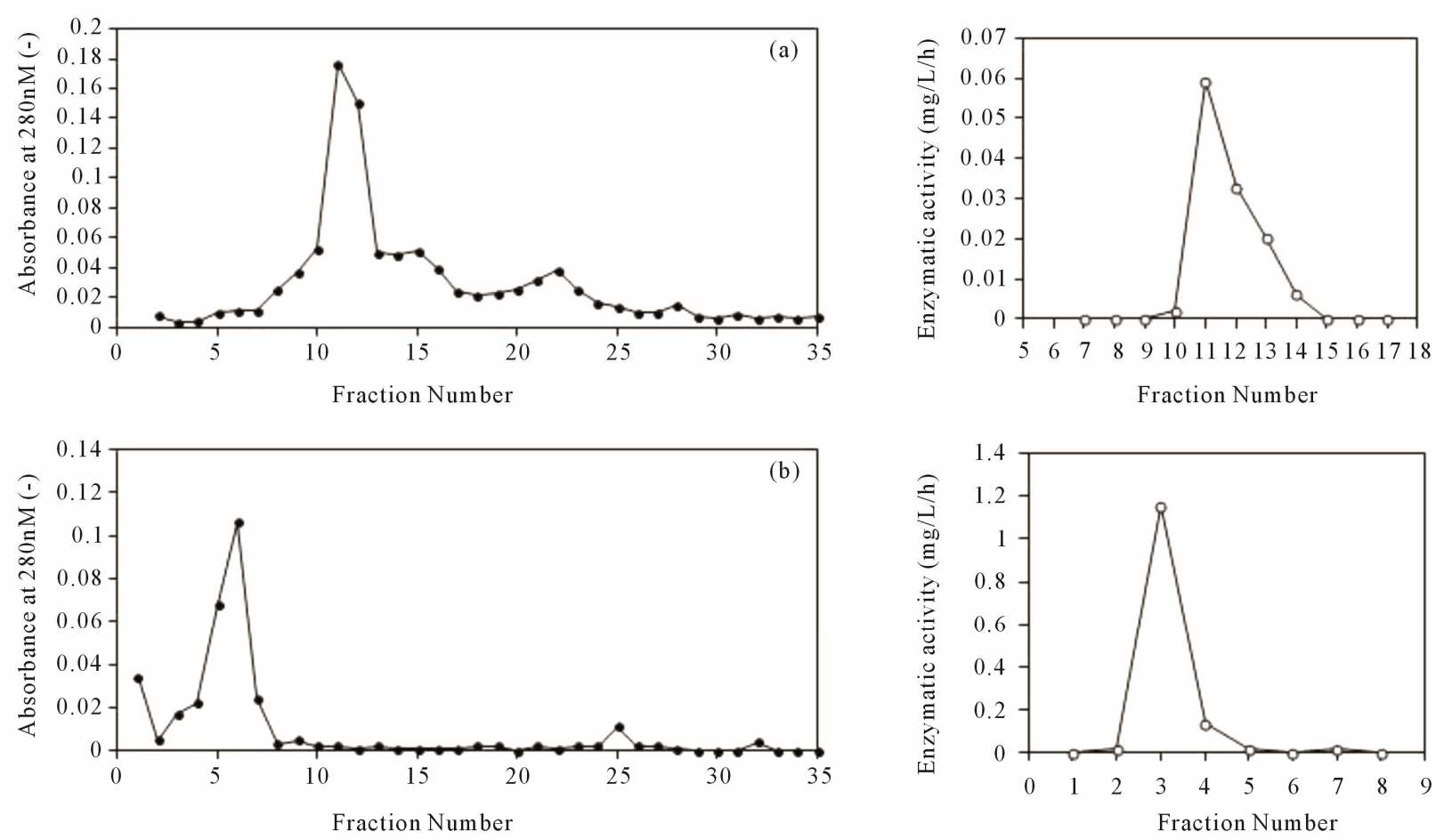

Figure 1. Purification of melamine deaminase using DEAE (a) and Sephadex G-100; (b) columns. The solid circles (right) indicate the absorbance at $245 \mathrm{~nm}$ in each fraction, and the open circles indicate the activity of melamine deaminase in the samples in which activity was present. 
ing of the strains for the ability to degrade cyanuric acid, because, cyanuric acid is a key intermediate in the metabolic pathway for melamine, it is nephrotoxic, and the cleavage of its ring is the rate-limiting step in the degradation process. The microorganisms present in soil were collected from 100 different places in three prefectures in Japan, and were grown on agar plates containing DM medium with $1.0 \mathrm{~g} / \mathrm{L}$ cyanuric acid. Finally, 10 strains were selected as cyanuric acid-degrading strains. The abilities of the ten strains to degrade triazine compounds, melamine and simazine, were tested. Three strains degraded melamine but did not degrade simazine. Four strains degraded simazine but did not degrade melamine. One strain weakly degraded both compounds, while the remaining two strains did not degrade either of them. The three melamine-degrading strains were named MEL1, MEL2 and MEL3, and the rates of cyanuric acid and melamine degradation in these strains were compared. The MEL1 strain showed the highest levels of degradation of cyanuric acid among them, although they showed the similar abilities to degrade melamine (data not shown). Thus, we used the MEL1 strain for further investigations.

The identification of the MEL1 strain was performed examining the nucleotide sequences of its $16 \mathrm{~S}$ ribosomal DNA. Figure 2 shows the phylogenic tree constructed by the neighbor-joining method. The MEL1 strain was placed in a cluster with Microbacterium esteramaticum, and the bootstrap value was high (92\%). The results of a homology research with the GeneBank/DDBJ/EMBL database also suggested that the MEL1 strain showed high homology to this organism. The homology between the MEL1 strain and the M. esteramaticum DMS8609 strain was $98 \%$. These results suggest that the species of the MEL1 strain is Microbacterium esteramaticum or that it was very similar to that species. The pathogenic effects of M. esteramaticum on plants and animals has not been reported, and therefore, the MEL1 strain is considered to be safe.

\subsection{Biochemical Characteristics of the MEL1 Strain}

The A. citrulli NRRL B-12227 strain showed a high ability to degrade melamine. Therefore, the enzyme activity in the MEL1 strain was compared with the A. citrulli NRRL B-12227 strain. As shown in Table 1, the specific activities of the melamine deaminase in these strains were similar. The melamine deaminase in the MEL1 strain was also purified and compared with that in the NRRL B-12227 strain. The specific activities after the purification processes are also shown in Table 1. The melamine deaminase was concentrated 77 times by these procedures. Figure 3 shows the results of the SDSPAGE-purified enzyme. The molecular weight of the melamine deaminase in the MEL1 strain was $65 \mathrm{kDa}$ (although there was still slight protein contamination present). This size was quite different from that isolated from the A. citrulli NRRL B-12227 strain (48 kDa) [17].

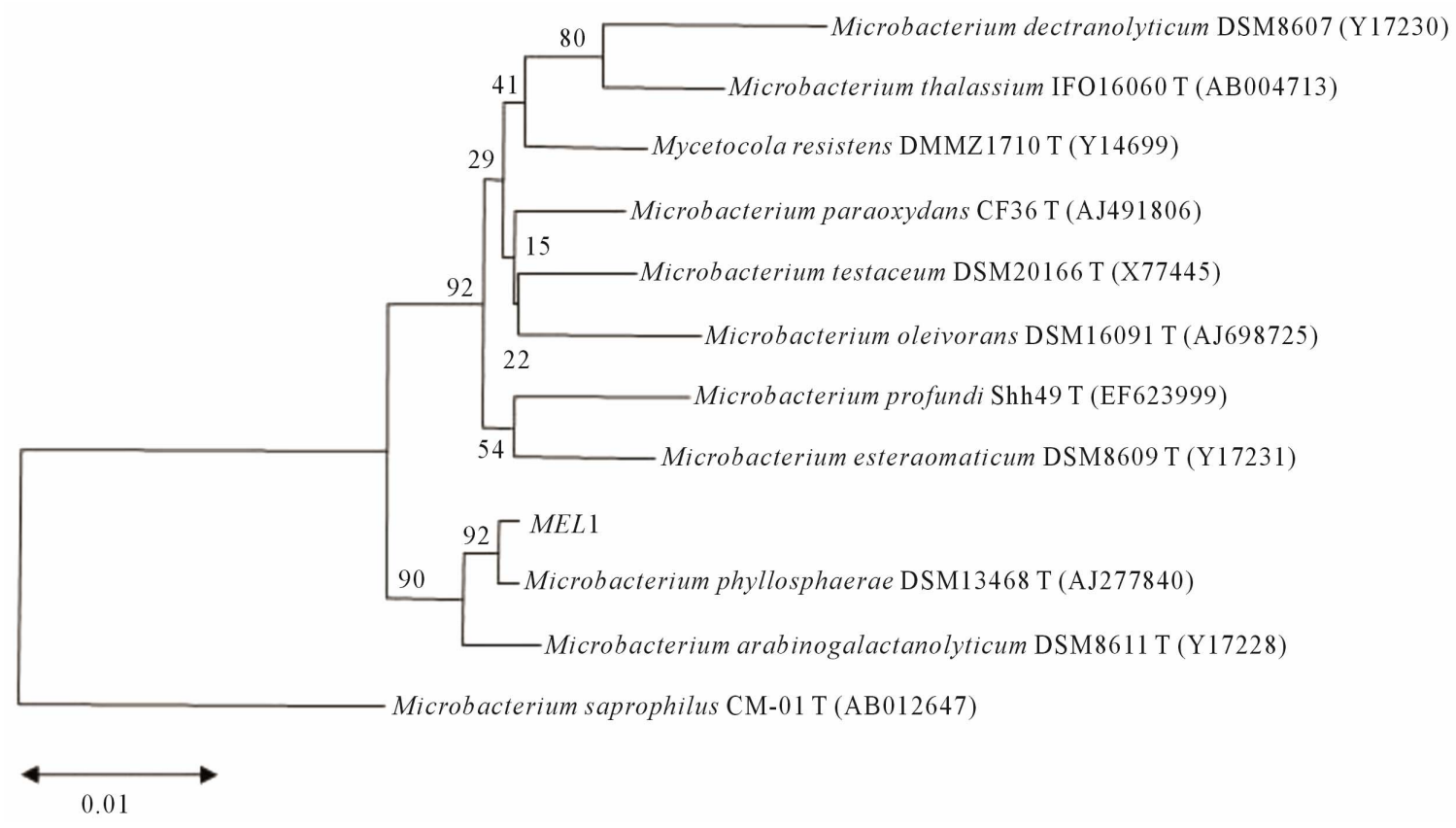

Figure 2. A phylogenetic tree based on the $16 \mathrm{~s}$ rDNA sequence data of the MEL1 strain. The relationship of the MEL1 strain to the most closely related 10 bacteria selected in the Apollon DB-BA Ver. 7.0 database are shown. The numbers at the branch points are bootstrap values, and the bar indicates a scale bar. The " $T$ " at the end of the strain names indicates a type strain. 
Table 1. Melamine deaminase activity in the MEL1 strain following the purification steps.

\begin{tabular}{cccccc}
\hline Purification & $\begin{array}{c}\text { Total } \\
\text { protein }\end{array}$ & $\begin{array}{c}\text { Total } \\
\text { activity }\end{array}$ & Recovery & $\begin{array}{c}\text { Specific } \\
\text { activity }\end{array}$ & Fold \\
\hline step & $(\mathrm{mg})$ & $(\mu \mathrm{g} / \mathrm{h})$ & $(\%)$ & $\begin{array}{c}(\mu \mathrm{g} / \mathrm{mg} \text { of } \\
\text { protein/h) }\end{array}$ & \\
(MEL1 strain) & & & & & \\
Crude soluble & 5.34 & 0.46 & 100 & 0.030 & 1.0 \\
$20 \%\left(\mathrm{NH}_{4}\right)_{2} \mathrm{SO}_{4}$ & 1.31 & 0.30 & 65 & 0.23 & 7.7 \\
$\begin{array}{c}\text { DEAE-cellulose } \\
\text { Sephadex } \\
\text { G-100 }\end{array}$ & 0.301 & 0.12 & 26 & 0.40 & 13.3 \\
$\begin{array}{c}\text { (NRRL } \\
\text { B-1227 strain) }\end{array}$ & 0.036 & 0.09 & 20 & 2.31 & 77.0 \\
\begin{tabular}{c} 
Crude soluble \\
\hline
\end{tabular} & & & & & \\
\hline
\end{tabular}
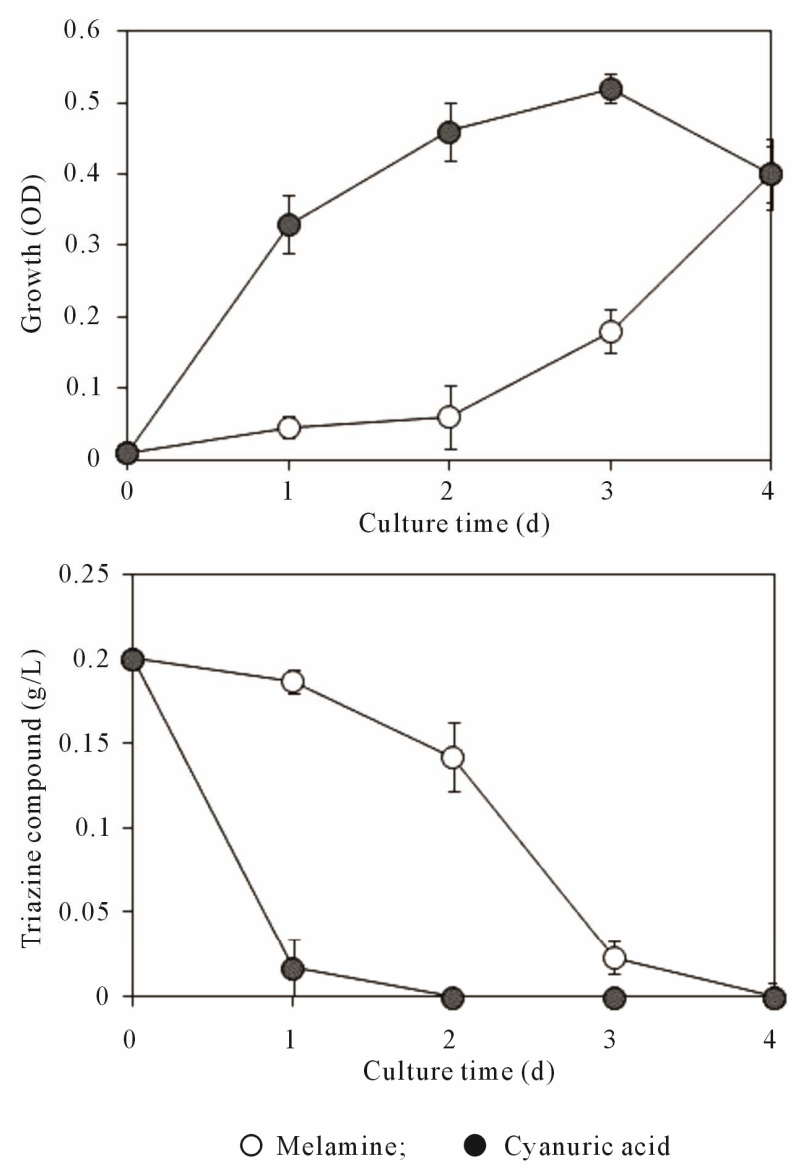

(a)

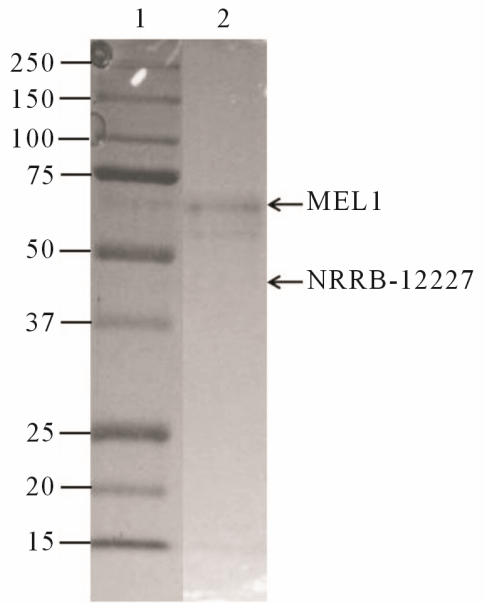

Figure 3. The SDS-PAGE separation of melamine deaminase. Lane A, protein standard; lane $B, 5 \mu \mathrm{L}$ of the solution concentrated from a fraction (No. 3) obtained during the Sephadex G-100 column chromatography. The arrows show the positions of melamine deaminases in the MEL1 and NRRL B-12227 strains.
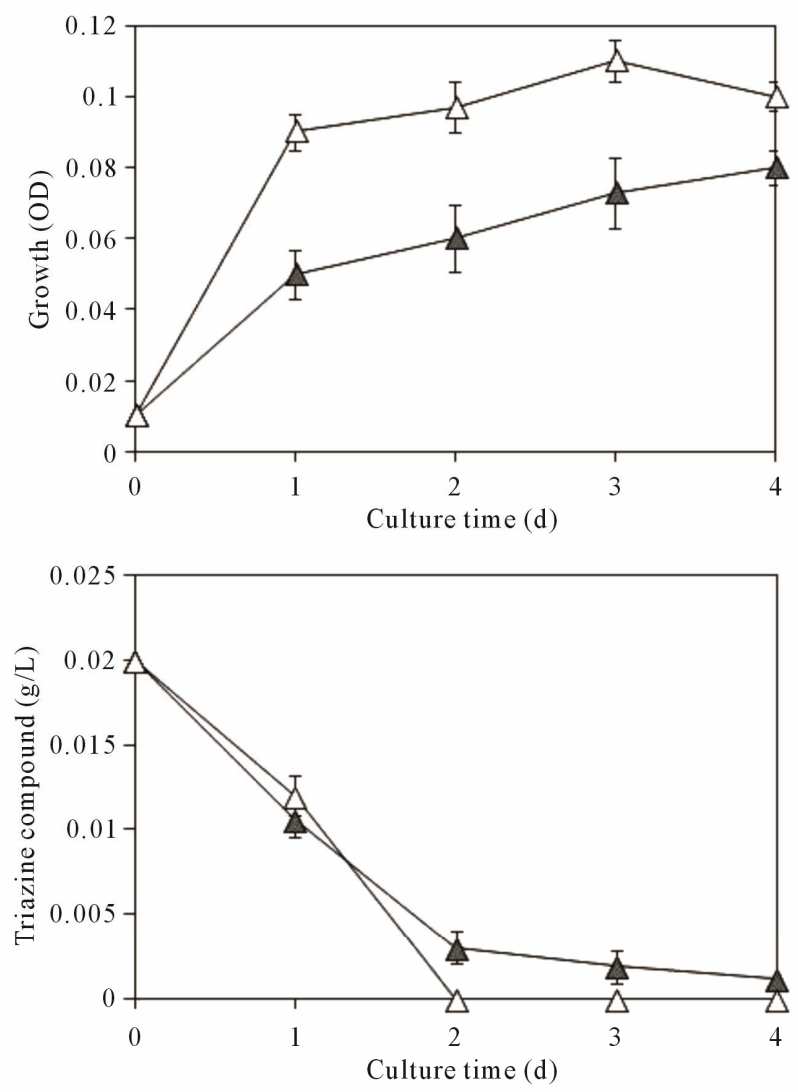

$\triangle$ Ammeline;

$\Delta$ Ammelide

(b)

Figure 4. Biodegradation of melamine and its related compounds by the MEL1 strain. The growth of the bacteria and concentrations of the compounds are shown when the MEL1 strain was respectively cultured in the DM medium containing 0.2 $\mathrm{g} / \mathrm{L}$ melamine or cyanuric acid (a), or $0.02 \mathrm{~g} / \mathrm{L}$ ammeline or ammelide (b). Bars, means \pm SD of 3 independent experiments. 


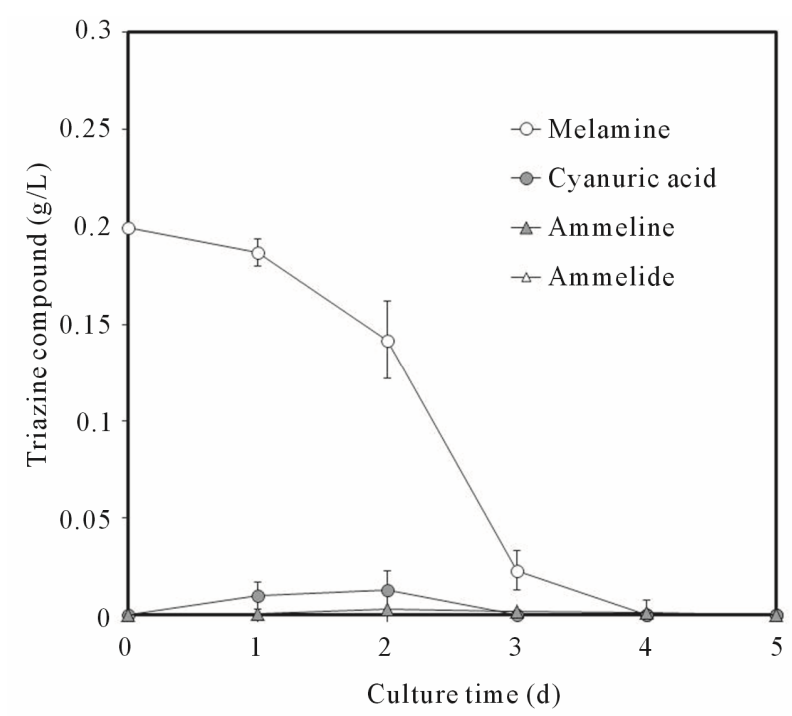

Figure 5. The time courses of the changes in the melamine concentration and the concentrations of its byproduct when the MEL1 strain was cultured in the DM medium containing melamine (as shown in Figure 4). Bars, means \pm SD of 3 independent experiments.

Finally, we examined the characteristics of melamine degradation in the MEL1 strain. Melamine was generally degraded to ammeline, ammelide and cyanuric acid in turn in bacteria [18]. Figures 4(a) and (b) show the growth of the bacteria and the concentration of triazine compounds when the MEL1 strain was respectively cultured in the DM media containing melamine, cyanuric acid, ammeline or ammelide. Lower concentrations were used in case of ammeline and ammelide, because they were difficult to dissolve at higher concentrations. The MEL1 strain could degrade all four of the triazine compounds as sole nitrogen sources, and the rates of melamine and cyanuric acid degradation were as high as those of other melamine-degrading strains [9-12]. Moreover, the degradation rate for cyanuric acid was faster than that for melamine.

Figure 5 shows the concentrations of melamine and its by-products when the bacteria were cultured in the DM medium containing melamine, as in Figure 4. As shown in Figure 5, cyanuric acid, ammeline and ammelide were not detected during the degradation of melamine. Because of toxicity, the minimal accumulation of cyanuric acid during the biodegradation of melamine is preferred, and therefore, the MEL1 strain might be useful for the bioremediation of melamine.

\section{Acknowledgements}

Our group is grateful to Ms. Syoko Sasaguri and Mrs. Madoka Yasui for their valuable assistance in conducting our research, and the NCIMB JAPAN Corporation for the identification of the MEL1 strain. This research was supported by grants-in-aids from the Central Laboratory and the School of Human Sciences at Kobe College.

\section{REFERENCES}

[1] D. Coulimbier, C. Hepner, S. Fabiansson, A. Tarantola, A. Cochet, P. Kreidl and R. Reintjes, "Melamine Contamination of Dairy Products in China-Public Health Impact on Citizens of the European Union," Eurosurvieillance, Vol. 13, No. 40, 2008, pp. 1-2.

[2] C. A. Brown, K.-S. Jeong, R. H. Poppenga, B. Puschner, D. M. Miller, A. E. Ellis, K.-I. Kang, S. Sum, A. M. Cistola and S. A. Brown, "Outbreaks of Renal Failure Associated with Melamine and Cyanuric Acid in Dogs and Cats in 2004 and 2007," Journal of Veterinary Diagnostic Investigation, Vol. 19, No. 5, 2007, pp. 525-531. doi: $10.1177 / 104063870701900510$

[3] S. A. Tittlemier, B. P. Lau, C. Ménard, C. Corrigan, M. Sparling, D. Gaertner, K. Pepper and M. Feeley, "Melamine in Infant Formula Sold in Canada: Occurrence and Risk Assessment," Journal of Agricultural Food Chemistry, Vol. 57, No. 12, 2009, pp. 5340-5344. doi:10.1021/jf9005609

[4] W. C. Anderson, S. B. Turnipseed, C. M. Karbiwnyk, S. B. Clark, M. R. Madson, C. M. Gieseker, R. A. Miller, N. G. Rummel and R. Reimschuessel, "Determination and Confirmation of Melamine Residues in Catfish, Trout, Tilapia, Salmon, and Shrimp by Liquid Chromatography with Tandem Mass Spectrometry," Journal of Agricultural Food Chemistry, Vol. 56, No. 12, 2008, pp. 43404347. doi: $10.1021 /$ if $800295 \mathrm{z}$

[5] S. L. Rovner, "Anatomy of a Pet Food Catastrophe", Chemical \& Engineering News, Vol. 86, No. 18, 2008, pp. 41-43. doi:10.1021/cen-v086n019.p041

[6] D. Park, T. K. Kim, Y. J. Choi, S. H. Lee, D.-K. Bae, G. Yang, Y.-H. Yang, S. S. Joo, E.-K. Chioi, B. Ahn, J.-C. Kim, K.-S. Kim and Y.-B. Kim, "Increased Nephrotoxicity after Combined Administration of Melamine and Cyanuric Acid in Rats," Laboratory Animal Research, Vol. 27, No. 1, 2011, pp. 25-28. doi:10.5625/lar.2011.27.1.25

[7] Y. Qin, X. Lv, J. Li, G. Qi, Q. Diao, G. Liu, M. Xue, J. Wang, J. Tong, L. Zhang and K. Zhang, "Assessment of Melamine Contamination in Crop, Soil and Water in China and Risks of Melamine Accumulation in Animal Tissues and Products," Environment Internarional, Vol. 36, No. 5, 2010, pp. 446-452. doi:10.1016/j.envint.2010.03.006

[8] D. R. Shelton, J. S. Karns, G. W. Mccarty and D. R. Durham, "Metabolism of Melamine by Klebsiella terragena," Applied and Environmental Microbiology, Vol. 63, No. 7, 1997, pp. 2832-2835.

[9] K. Takagi, K. Fujii, K. Yamazaki, N. Harada and A. Iwasaki, "Biodegradation of Melamine and Its Hydroxy Derivatives by a Bacterial Consortium Containing a Novel Nocarduoides Species," Applied Microbiology and Biotechnology, Vol. 94, No. 6, 2012, pp. 1647-1656.

[10] J. K. Karns, "Gene Sequence and Properties of an s-Tri- 
azine Ring-Cleavage Enzyme from Pseudomonas sp. Strain NRRLB-12227" Applied and Environmental Microbiology, Vol. 65, No. 8, 1999, pp. 3512-3517.

[11] K. Jutzi, A. M. Cook and R. Hütter, "The Degradative Pathway of the s-Triazine Melamine," Biochmical Journal, Vol. 208, 1982, pp. 679-684.

[12] N. Shiomi, Y. Yamaguchi, H. Nakagi, T. Fujita, T. Katusda and S. Katoh, "Degradation of Cyanuric Acid in Soil by Pseudomonas sp. NRRL B-12227 Using Bioremediation with Self-Immobilization System," Journal of Bioscience and Bioengineering, Vol. 102, No. 3, 2006, pp. 206-209. doi:10.1263/ibb.102.206

[13] N. W. Schaada, E. Postnikovaa, A. Sechlera, L. E. Claflinb, A. K. Vidaverc, J. B. Jonesd, I. Agarkovac, A. Ignatove, E. Dicksteind and B. A. Ramundob, "Reclassification of Subspecies of Acidovorax avenae as A. Avenae (Manns 1905) emend., A. cattleyae (Pavarino, 1911) comb. nov., A. citrulli (Schaad et al., 1978) comb. nov., and Proposal of A. oryzae sp. nov.," Systematic and Applied Microbiology, Vol. 31, 2008, pp. 434-446. doi:10.1016/j.syapm.2008.09.003
[14] N. Saitou and M. Nei, "The Neighbor-Joining Method: a New Method for Reconstructing Phylogenetic Trees," Molecular Biology and Evolution, Vol. 4, No. 4, 1987, pp. 406-425.

[15] S. F. Altschul, T. L. Madden, A. A. Schäffer, J. Zhang, Z. Zhang, W. Miller and D. J. Lipman, "Gapped BLAST and PSI-BLAST: A New Generation of Protein Database Search Programs," Nucleic Acids Research, Vol. 25, No. 17, 1997, pp. 3389-3402. doi:10.1093/nar/25.17.3389

[16] U. K. Laemmli, "Cleavage of Structural Proteins during the Assembly of the Head of Bacteriophage T4," Nature, Vol. 227, 1970, pp. 680-685. doi:10.1038/227680a0

[17] J. L. Seffernick, M. L. de Souza, M. J. Sadowsky and L. P. Wackett, "Melamine Deaminase and Atrazine Chlorohydrolase: 98 Percent Identical but Functionally Different," Journal of Bacteriology, Vol. 183, No. 8, 2001, pp. 24052410. doi:10.1128/JB.183.8.2405-2410.2001

[18] R. W. Eaton and J. S. Karns, "Cloning and Analysis of sTriazine Catabolic Genes from Pseudomonas sp. Strain NRRLB-12227," Journal of Bacteriology, Vol. 173, No. 3, 1991, pp. 1215-1222. 